\title{
Strategic Role, Challenges And Opportunities For Small And Medium Enterprises Facing DR-CAFTA: The Case Of Costa Rica
}

\author{
Arístides R. Baraya, (E-mail: abaraya@selu.edu), Southeastern Louisiana University \\ Michael C. Budden, (E-mail: mbudden@selu.edu), Southeastern Louisiana University \\ Lizette Brenes Bonilla, (E-mail: lbrenesb@uned.ac.cr), Universidad Estatal a Distancia, Costa Rica
}

\begin{abstract}
The development of regional business treaties and the subsequent removal of trade barriers has created new paradigms and challenges for companies in Latin America, especially in fast-growing Central America. This paper examines the role, challenges, and opportunities for small and medium enterprises (SME's) in Costa Rica relative to the Dominican Republic-Central American Free Trade Agreement (DR-CAFTA, or CAFTA in the US). Opportunities and challenges facing SME's and the potential impact of DR-CAFTA on industry performances in Costa Rica are discerned. Central American nations and Costa Rica in particular, are facing new challenges, threats and opportunities that arise from trade agreements. Such is the case with DR-CAFTA. These paradigms and competitive pressures will directly impact external trade and sustainable economic development. Opportunities are associated with new laws and regulations, incentives to reinforce and improve business practices especially with regard to human capital, as well as new scenarios for international cooperation, commercial agreements and the growing use of outsourcing. The implications of DR-CAFTA are far-reaching and directly impact the development of small and medium enterprises in Costa Rica.
\end{abstract}

\section{INTRODUCTION AND BACKGROUND}

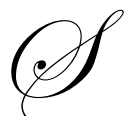

ME's in Latin America represent an important resource. Their importance has finally become accepted as employment, production, and exportation are increasingly impacted. In Costa Rica, 95\% or the country's industrial park sites are occupied by SME's. They produce almost one third of the nation's GDP and generate more than $50 \%$ of the employment in the private sector. The importance and impact of SME's has evolved into an accepted reality not only by the private sector but by the government. The government now encourages and supports SME activities.

Using definitional parameters of the Ministry of Economy, Industry and Commerce of Costa Rica (MEIC), there are 3.65 SME's for every 1000 habitants. Chart 1 presents the MEIC parameters. Service providers comprise the largest percentage of SME's (37\%), followed by commercial activities (25\%), industrial (15\%), agriculture (15\%) and construction (6\%).

According to the Union of Chambers and Associations for Private Enterprises (UCCAEP, 2004), the "engines" of the country's economy are tourism and exporting. The country has broadly diversified its exportable offerings: more than 3500 products to 138 countries worldwide, produced by 1744 enterprises. However, the proportion of exports represented by SME's has remained small compared to large firms. Conversely, SME's contribution in the tourism industry has become significant and positive. SMEs have helped attract more than 1.400.000 tourists during 2004, generating approximately U.S. \$1,500 millions. 
Chart 1

Characteristics of SME's*

\begin{tabular}{|l|l|l|}
\hline \multicolumn{1}{|c|}{ Size } & \multicolumn{1}{|c|}{ Requisites } & \multicolumn{1}{c|}{ Characteristics } \\
\hline Micro-enterprise & Number of employees & 1 to10 including the owner \\
& Annual sales & Up to $\$ 150.000$ \\
\hline Small Enterprise & $\begin{array}{l}\text { Number of employees } \\
\text { elements } \\
\text { Annual sales }\end{array}$ & 6 to 30 \\
\hline Medium Enterprise & $\begin{array}{l}\text { Number of employees } \\
\text { Investment in equipment, machinery and other } \\
\text { elements }\end{array}$ & Up to $\$ 500.000$ \\
& Annual sales $\$ 250.000$ \\
\hline Large Enterprise & $\begin{array}{l}\text { Number of employees } \\
\text { Investment in equipment, machinery and other } \\
\text { elements }\end{array}$ & More than $\$ 500.000$ \\
\hline
\end{tabular}

*From the MEIC

According to the Ministry of Economy, Industry and Commerce (2004):

- $\quad 95 \%$ of the 4842 enterprises that compose the formal industrial sector in Costa Rica qualify as SME's, with less than 100 employees

- $\quad$ SME's correspond to $28 \%$ of Costa Rica's GDP

- SME's with less than 20 employees hire $26 \%$ of the country's employees and provide $51 \%$ of the jobs in the private sector

- $\quad$ SME's represented $14 \%$ of the exportation market during 2004.

The role and importance of the SME's is not limited to developing countries. According to the InterAmerican Development Bank (Rosales, 2001), SME's have become the main innovative force in industrialized countries and represent more than $60 \%$ of the enterprises. In developing countries; SMEs' participation reaches $90 \%$ of the total number of enterprises. In Costa Rica the figure is more than $95 \%$.

Costa Rica's future development depends in part on the performance of the SME sector. However, the current situation could be described as a "cocktail" that offers an unprecedented situation for SME's. The combination of new laws, new commercial agreements and new programs for support, could confuse a small entrepreneur who is completely absorbed in his/her daily activities. These conditions make it necessary to implement a strategic approach in order to improve SME's competitiveness. 


\section{THE COSTA RICA CASE}

In August of 2004, UNED (The Costa Rican Distance Learning University) interviewed 314 entrepreneurs who participated in PYMES' (micro, small and medium enterprises) training activities. The objective was to identify priority training and advisory needs of entrepreneurs. Managers or owners of 314 SMEs from around the country were surveyed and the results showed priority necessities that can be classified into three different topic areas: financial/accounting $83 \%$, sales, merchandising and service $71 \%$ and techniques (technologies, quality, information technology, production) $63 \%$. Not surprisingly, $91 \%$ felt their enterprise did not devote enough time to training. Of the $77 \%$ who had management decision control, $82 \%$ considered that they had to make decisions lacking sufficient information.

Trying to identify a strategic approach for SMEs to face this situation adequately was a goal. Kaplan and Norton (2001) recommended that four perspectives should be considered in strategic management: financial, client, human resources and internal procedures. SMEs' characteristics provoke a gap between their strategic competencies and those of larger firms. Acs, Arenius and Hay (2004), found that the time a manager/owner of a PYME devotes to training and formation is $40 \%$ of what the manager of a large enterprise spends, and generally relates to technical aspects of production. Due to this, we will now present five concrete challenges, oriented to the strategic strengthening of the competences of PYMES. This list does not pretend to be exhaustive; rather, it is based on priorities. The first one is oriented towards the need to improve the competencies to export; a sector in which PYMES are under-represented and the rest are related to competencies to strategically manage, based on the four perspectives within the Integral Management Framework (Acs, Arenius and Hay, 2004).

\section{CHALLENGES}

\section{First Challenge: To Improve Exporting Competencies}

Due to low participation of SMEs, the challenge is to:

- $\quad$ Increase the amount exported by SMEs

- $\quad$ Increase the number of exporting SMEs

- $\quad$ Increase the value of SME exports

It appears that Costa Rica businesses have not taken advantage fully of existing commercial agreements. For example, based on the country's 2004 balance of trade, the country's best trade partners are:

- $\quad$ Central American neighbouring countries, including Panama, whose total positive balance of trade is equivalent to US\$458 million

- $\quad$ The Dominican Republic whose positive balance was worth US\$62 million

- $\quad$ Canada with a positive balance of US\$162 million

On the other hand, Costa Rica's current treaties with Mexico and Chile have resulted in negative balance of trade with these two countries. The balance in favor of Mexico, in 2004, was equivalent to US\$247 millions, while Chile's was US\$73.2 million. In short, it appears that even before DR-CAFTA, Costa Rican enterprises have not realized fully, trade opportunities.

\section{Second Challenge: To Improve Financial Competencies}

Although entrepreneurs often make financial decisions, their ability to gather and analyze sufficient information may prevent optimal decisions. As a result, the challenge is to include a review of the current financial outcomes of the enterprise, especially, costs. Small entrepreneurs need to understand indirect costs as they are becoming increasingly important. The indirect costs related to different types of clients could offer new information in the decision-making process. The analysis of new stages to improve the financial position of the enterprise becomes a 
challenge that cannot be ignored by entrepreneurs who wants to be competitive, provided that a new product, a better service or another financial opportunity could improve the competitive advantage.

\section{Third Challenge: To Improve Client-Related Competencies}

The entrepreneur must pay attention to the quality of the service he/she is rendering. The entrepreneur must take understand that improvements to products and services must be a continual effort. The strategic approach could be oriented towards maintaining current SME clients and less in the direction of finding new clients. The 20/80 rule, where $20 \%$ of one's customers account for $80 \%$ of one's sales needs to be ingrained in SMEs. Training focusing on people skills and understanding The Marketing Concept, where customers are king, is needed.

\section{Fourth Challenge: To Improve Process Related Competencies}

Opportunities to improve products and services exist. Quality improvement is an expectation in most industries worldwide. The implementation of new technologies, the quest for innovation, and for quality and continuous improvement is paramount. SMEs are generally among the latter users of technologies and often must play catch up to their larger counterparts. SMEs need training to improve processes, as with other commercial competencies.

\section{Fifth Challenge: To Improve Competencies Related With Learning And Development}

Learning and employee development relates directly to continuous improvement in all operative levels of a company. In Costa Rica, the opportunities to receive training are ample. For example, the National Institute for Apprenticeship (INA) offers varied technical training opportunities. Universities like UNED, and organizations such as FUNDES, offer training programs for entrepreneurs. The Chamber of Industries' Institute for Business Excellence offers a competitive program through which firms demonstrating outstanding quality can win nationwide awards for excellence. The Chamber also offers training and marketing vehicles that promote efforts of its members. Recently, an innovation carried out by the Development Bank of the National Bank has been added: called Expocapacita, it includes merchandising stands for entrepreneurs who have credit with the bank, and negotiation and training spaces.

The challenges that have been presented are not the only ones, but they are the most important ones from the strategic dimension's point of view for PYMES at this time.

\section{OPPORTUNITIES}

The opportunities presented to SMEs have no precedents. For SMEs to address the challenges mentioned, they need to be aware of opportunities presented. They are framed in three areas: institutional support, new commercial agreements, and outsourcing strategies of large enterprises and institutions.

\section{First Opportunity Area: Institutional Support}

Institutional support is available from a variety of sources. The importance of SME participation is underscored by a new law, and other efforts including a loan recently obtained through the InterAmerican Development Bank, and support offered by the European Community.

The most recent Costa Rican effort is the Law to Strengthen Small and Medium Sized Enterprises (Law No. 8262). This law establishes a coordinated effort between different institutions and ministries; among them, universities. It creates an Advising Board for the Ministry of Economy Industry and Trade. It designates a Bank to grant financing with a fund specializing in SMEs. Additionally, the law establishes a fund to strengthen innovation and technological development for the SMEs. 


\section{Second Opportunity Area: New Commercial Agreements}

The current situation includes the growing commercial importance and the possible ratification by Costa Rica of DR-CAFTA. This free trade agreement between the United States, Central America and the Dominican Republic emphasizes the need for small enterprises to strengthen their competitiveness in order to face the challenges of an increasingly open and competitive marketplace.

\section{Third Opportunity Area: Outsourcing}

Several strategies to improve competitiveness exist. One strategy involves the outsourcing of supply or services. Outsourcing holds promise for SMEs. Opportunities for Costa Rican SMEs to provide and/or profit from outsourcing include most industries, including those involved in the provision of services, including training, research and consulting.

\section{CONCLUSIONS}

- $\quad$ SMEs are numerous and their competitive capacity is crucial to the continued development of Costa Rica (and other developing countries).

- $\quad$ SMEs face challenges and opportunities that large firms may ignore. The complexity of the environment requires great efforts that must be approached strategically.

- $\quad$ SMEs must be strengthened. Efforts must be oriented to overcome identified weaknesses. Finance and marketing training should be central in this effort.

- If these competencies are strengthened, SMEs could take advantage of opportunities that converge, such as the ones undertaken by the law for their strengthening, credit options and support services for development.

- $\quad$ Our study indicates that SMEs in Costa Rica could benefit, however, parallelisms with other developing economies, especially in Central America are evident and thus, SMEs throughout Central America could benefit from a coordinated support effort by their respective governments and NGOs.

\section{REFERENCES AND OTHER SOURCES}

1. Acs, J., Arenius. P. y Hay. P. Minniti, M. Global Entrepreneurship Monitor 2004 Executive Report. Recuperado en http://www.gemconsortium.org/ julio 05, 2005

2. Amenavar, A. (2005) Infraestructura compatible con la ecología. Revista Actualidad Económica. No312-313.

3. Asamblea Legislativa de la República de Costa Rica. (2002) Ley de fortalecimiento de las pequeñas y medianas enterprises. No 8262. Costa Rica.

4. Asamblea Legislativa de la República de Costa Rica. Documento de trabajo. Comisión especial mixta que analiza el sistema integral de apoyo que requiere la pequeña y mediana industria costarricense para fortalecer su competitividad y su internacionalización. Expediente $n^{\circ} 13.823$-2001. Costa Rica.

5. Brown, T, Crainer, S, Dearlove, D, Rodríguez, J (2002) Business Minds. Prentice Hall. Madrid.

6. Barber, F y Stack, R. La sorprendente economía de una empresa de personas. Harvard Business Review. Recuperado en http://www.hbral.com/sp/revista/contenido.asp?id=886, 17 de junio, 2005.

7. Castillo, G y Chaves, L.(2001) PYMES: una oportunidad de desarrollo para Costa Rica. FUNDES.

8. Enriquez, J. (2004) Mientras el futuro te alcanza. Circulo cultural Azteca. México.

9. Ferro, R (2005) El motor de la economía es la mente de su gente Actualidad Económica Digital. Recuperado en www.americaeconomia.com

10. Kaplan, R, y Norton D. (2001) Como utilizar el cuadro de Mando Integral. Ediciones gestión 2000. Madrid.

11. La adaptación de la empresa al contexto difícil el modelo "Biasca" para cambiar Recuperado en: http://www.biasca.com/articulos/nuevoarticulo_10_01.html, 26 de junio de 2005.

12. Loría, M. y Monge, R. (2002) Telecomunicaciones y la competitividad para PYMES. CAATEC. Costa Rica.

13. Ministerio de Comercio Exterior. Agenda Integral de Cooperación-CAFTA-RD. Recuperado en www.comex.go.cr, 03 de junio, 2005.

14. Porter, M. (1996) Ventaja competitiva. Decimatercera reimpresión. CECSA. México.

15. Macaya, G. Cruz, A. Situación actual C y T. Estrategia Siglo XXI. San José. Proyecto CR-USA. 
16. Rosales, Miguel. (2001) Entrevista sobre PYMES. IDB. EE UU.

17. UCCAEP.(2004) Situación económica 2004 y perspectivas para 2005. Nota Técnica 07-04

18. For information on Costa Rica, PYMES, SMEs and other factors of Costa Rican Business, visit the following sites: www.caatec.org, www.crecex.org, www.eclac.cl/, www.fundes.org, www.incae.ac.cr, www.procomer.com, www.sieca.org.gt/

\section{NOTES}

